\title{
Effect of long-term irrigation water salinity on soil properties and microbial biomass
}

\author{
*Adele Muscolo, *Carmelo Mallamaci, **Maria Rosaria Panuccio, \\ ***R. Caputo, ***Stefania De Pascale \\ *Department of Agricolture Forest System Management, Agricolture Faculty, \\ "Mediterranea" University Feo di Vito, 89126 Reggio Calabria, Italy \\ e-mail: amuscolo@unirc.it \\ **Faculty of Agriculture, University Mediterranea, University Mediterranea, \\ Salita Melissari-III Lotto, 89124 Reggio Calabria, Italy \\ ***Department of Agricultural Engineering and Agronomy, University of Naples Federico II, \\ Via Università 100, 80055 Portici (Na), Italy
}

Summary. We assessed the effects of saline water irrigation on soil properties and microbial activity. Increasing salinity microbial activity decreased. $1 \%$ salinity strongly affected soil biochemical properties and microorganisms. Our results indicate that $0.5 \%$ salinity may be tolerated by soil microorganisms suggesting a possible use of brackish water in agriculture soils.

Key words: brackish water, enzyme activity, microbial biomass $\mathrm{C}$, soil organic matter.

\section{Introduction}

Salinization is a process of soil degradation that is increasing in importance through the world (Liang 2005). Primary salinization is a natural phenomenon involving accumulation of salts through natural processes due to high salt contents in parent materials or ground water. Secondary salinization is a big problem in irrigated agriculture. Indiscriminate flood irrigation with poor drainage facilities, deep plowing of marginal and naturally saline soils, overexploitation of groundwater, recycling of drainage outflows for irrigation, and mono-cropping of high water consumptive crops are the major factors accelerating secondary soil salinization in Mediterranean regions and in Central Asia (Qushimov et al. 2007). The objective of this study was to assess the effects of long-term irrigation-induced salinity on soil properties and microbial biomass activity in a clayloam soil located in the Agronomy Farm "Torre Lama" located at the University of Naples, Southern Italy. During the dry season, the soils have been irrigated with saline water for 23 years.

\section{Research methods}

Soils had been irrigated since 1988 with three saline treatments: $0.0 \%, 0.5 \%$ and $1.0 \% \mathrm{w} / \mathrm{v} \mathrm{NaCl}$. Saline water was obtained by adding commercial sea salt $\left(\mathrm{Na}^{+} 12.3 \mathrm{~mol} \cdot \mathrm{kg}^{-1}\right.$; $\mathrm{K}^{+} 3.8 \mathrm{~mol} \cdot \mathrm{kg}^{-1} ; \mathrm{Ca}^{2+} 0.02 \mathrm{~mol} \cdot \mathrm{kg}^{-1}, \mathrm{Mg}^{2+} 0.04 \mathrm{~mol} \cdot \mathrm{kg}^{-1}, \mathrm{Cl}^{-}$ $\left.14.4 \mathrm{~mol} \cdot \mathrm{kg}^{-1}, \mathrm{SO}_{4}{ }^{2-} 0.03 \mathrm{~mol} \cdot \mathrm{kg}^{-1}\right)$ to the irrigation water. The soils were sampled from three random locations in each treatment area and analyzed for chemical, biochemical and microbial activity Soil chemical analysis, microbial 
biomass $\mathrm{C}(\mathrm{MBC})$, and enzyme activities were detected as reported in Muscolo et al. (2007) and Sidari et al. (2008).

\section{Results and discussion}

The results showed that the $0.5 \%$ salinity treatment didn't affect soil chemical properties compared to control (Tab. 1), but it decreased MBC, and soil enzyme activities, except for FDA. There was a significant negative effect of $1 \%$ salinity level on soil organic matter dynamic, demonstrated by the accumulation of organic matter, the increase of Humic to Fulvic Carbon (HC/FC) ratio and the decrease of Humic Carbon to Total Carbon ratio (HC/TC) ratio (Tab. 1). MBC, and the indices of microbial activity (urease, acid and alkaline phosphatases, catalase, protease and fluorescein diacetate hydrolysis rates), were all negatively related to salinity treatments except for protease, and both phosphatases (Tab. 2). These results indicate that the increase of salinity resulted in a progressively smaller, more stressed microbial community which was less metabolically efficient. These findings were confirmed through the progressive increase in soil phenols and polyphenols that are generally microbially produced in stressful conditions (Tab. 1). It is evident that $0.5 \%$ salinity doesn't have such a negative effect on soil chemical and properties but at high concentration, it extremely affects number and activity of soil microbial biomass and biochemical processes, essential for the maintenance of soil quality. This will result in a reduction of the rate of soil organic matter decomposition and of $\mathrm{C}, \mathrm{N}$, and $\mathrm{P}$ mineralization. The resulting reduced nutrient availability will be an additional growth-limiting factor to crop production in salt-affected soils. Furthermore, the relationships with saline concentration demonstrate that long-term irrigation with saline water up to $0.5 \%$ salinity doesn't have such a detrimental effect on soil microbial community and organic matter dynamic, as also demonstrated by FDA values. On the basis of these findings we suggest a possible utilization of $0.5 \%$ salinity brackish water in agriculture.

\section{References}

Liang Y., Nikolic M., Peng Y., Chen W. \& Jiang Y., 2005, Organic manure stimulates biological activity and barley growth in soil subject to secondary salinization, Soil Biol. Biochem. 37: 1185-1195.

Muscolo A., Sidari M. \& Mercurio R., 2007, Variations in soil chemical properties and microbial biomass in

Table 1. Chemical characteristics of long- term water salinity irrigated soils. Numbers denote the standard errors $(n=9)$. Organic Carbon (OC\%); Organic Matter (OM\%); Humic Carbon (HC\%); Fulvic Carbon (FC\%); Total Nitrogen (N\%); Cation Ex-

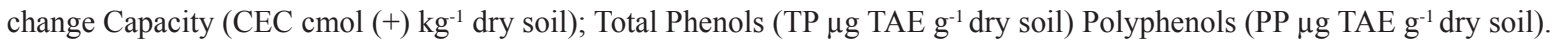
Numbers denote the standard errors $(\mathrm{n}=9)$

\begin{tabular}{|l|c|c|c|c|c|c|c|c|c|c|c|c|}
\hline $\begin{array}{c}\text { Treat- } \\
\text { ment } \\
{[\%]}\end{array}$ & OC & OM & HC & FC & $\begin{array}{c}\text { HC/ } \\
\text { FC }\end{array}$ & $\begin{array}{l}\text { HC/ } \\
\text { TC }\end{array}$ & N & C/N & Texture & CEC & TP & PP \\
\hline 0 & $1.21 \pm 0.01$ & $2.10 \pm 0.1$ & $0.80 \pm 0.2$ & $0.47 \pm 0.1$ & 1.70 & 66.6 & $0.12 \pm 0.007$ & 10.1 & Clay-Loam & $18 \pm 0.5$ & $6.747 \pm 0.5$ & $1.655 \pm 0.3$ \\
\hline 0.5 & $1.38 \pm 0.03$ & $2.37 \pm 0.1$ & $0.91 \pm 0.1$ & $0.51 \pm 0.1$ & 1.78 & 65.9 & $0.13 \pm 0.005$ & 10.6 & Clay-Loam & $18 \pm 0.3$ & $22.013 \pm 0.9$ & $2.799 \pm 0.5$ \\
\hline 1.0 & $1.70 \pm 0.02$ & $2.92 \pm 0.1$ & $0.75 \pm 0.2$ & $0.38 \pm 0.1$ & 1.97 & 44.1 & $0.12 \pm 0.003$ & 14.0 & Clay-Loam & $18 \pm 0.5$ & $67.271 \pm 1.5$ & $4.083 \pm 0.6$ \\
\hline
\end{tabular}

Table 2. Microbial Biomass (MBC $\mu \mathrm{g} \mathrm{C} \mathrm{g}^{-1}$ soil), fluorescein diacetate (FDA) hydrolysis (fluorescein released, $\mu \mathrm{g} \mathrm{g}^{-1} \mathrm{dry} \mathrm{soil}$ ), catalase $\left(\mathrm{CAT} \mu \mathrm{molO}_{2}\right.$ min/g soil); acid phosphatase (Ac.P $\mu \mathrm{g} p$-nitrophenol $\mathrm{g}^{-1} \mathrm{~h}^{-1}$ ), alkaline phosphatase (Ak. P. $\mu \mathrm{g} p$-nitrophenol g ${ }^{-1} \mathrm{~h}^{-1}$ ) and urease (URE $\mu \mathrm{N} \mathrm{NH}_{4}^{+}-\mathrm{N} \mathrm{g}^{-1}$ dry soil $2 \mathrm{~h}^{-1}$ ), Protease (PRO mg tyrosine $\mathrm{g}^{-1}$ dry soil $2 \mathrm{~h}^{-1}$ ) activities, in long- term water salinity irrigated soils. Numbers denote the standard errors $(n=9)$

\begin{tabular}{|l|c|l|l|l|l|l|l|}
\hline $\begin{array}{c}\text { Treatment } \\
\text { [\%] }\end{array}$ & FDA & \multicolumn{1}{|c|}{ CAT } & \multicolumn{1}{|c|}{ PRO } & URE & \multicolumn{1}{c|}{ Ac.P } & Ak.P & \multicolumn{1}{c|}{ MBC } \\
\hline 0 & $25.31 \pm 0.6$ & $2.57 \pm 0.5$ & $0.156 \pm 0.9$ & $84.72 \pm 1.9$ & $250 \pm 3.9$ & $432 \pm 3.9$ & $843.2 \pm 3.7$ \\
\hline 0.5 & $63.16 \pm 0.9$ & $1.48 \pm 0.3$ & $0.116 \pm 0.7$ & $80.95 \pm 1.2$ & $145 \pm 1.5$ & $326 \pm 2.8$ & $645.5 \pm 2.9$ \\
\hline 1 & $21.84 \pm 0.4$ & nd & $0.357 \pm 0.9$ & $78.40 \pm 0.9$ & $98 \pm 1.9$ & $144 \pm 1.5$ & $201.2 \pm 1.6$ \\
\hline
\end{tabular}


artificial gaps in silver fir stands, European Journal of Forest Research 126: 59-65.

Sidari M., Ronzello G., Vecchio G. \& Muscolo A., 2008, Influence of slope aspects on soil chemical and biochemical properties in a Pinus laricio forest ecosystem of Aspromonte (Southern Italy), European Journal of Soil Biology 44: 364-372.

Qushimov B., Ganiev I. M., Rustamova I., Haitov B. \& Islam K. R., 2007, Land degradation by agricultural ac- tivities in Central Asia, [in:] R. Lal, M. Sulaimonov, B. A. Stewart, D. Hansen, P. Doraiswamy (eds.), Climate change and terrestrial $\mathrm{C}$ sequestration in Central Asia, Taylor and Francis, New York: 194-212. 